\section{International Scientific Journal Theoretical \& Applied Science}

p-ISSN: 2308-4944 (print) e-ISSN: 2409-0085 (online)

Year: $2018 \quad$ Issue: $06 \quad$ Volume: 62

Published: 01.06.2018 http://T-Science.org

SECTION 9: Chemistry and chemical technology
Oleg Ivanovych Yurchenko Kharkiv V.N. Karazin National University, PhD, Full Professor of Chemical Metrology Department, yurchenko@karazin.ua

Nadegda Petrovna Titova Kharkiv V.N. Karazin

National University, Researcher of Chemical Metrology Department, yurchenko@karazin.ua

Tetyana Vasylivna Chernozhuk Kharkiv V.N. Karazin

National University, PhD, Associate Professor of Inorganic Chemistry Department, tanya.chernozhuk@gmail.com

Oleksii Andriovych Kravchenko Kharkiv V.N. Karazin

National University, $\mathrm{PhD}$, Associate Professor of Chemical Metrology Department, alekseykravch@ukr.net

\title{
ATOMIC-ABSORPTION AND ATOMIC-EMISSION WITH INDUCTIVE CONNECTED PLASMA DETERMINATION OF THE ANALYTS IN OIL PRODUCTS WITH USE OF MODERN METHODS OF SAMPLE PREPARATION AND NEW STANDARD COMPOSITION SAMPLES
}

Abstract: An influence of concentration of surfactants and time of ultrasound treatment on value of analytical signal at atomic-absorption and atomic-emission with inductive connected plasma determination of analysts in oil products was studied. It was shown that using of our sample preparation increases sensibility in 1,5-2,0 times. These results were also proved by the new processing program. By means of by variation of the sample mass we show an absence of perfect systematical error. By the method "injected-found out" an accuracy of the results of atomic-absorption determination of Zinc and Manganese was estimated. Coherence of the results, obtained by two independent methods, was estimated by F-and t-criteria. It was shown that dispersions are homogenous and results are distinguished not sufficiently. We also estimated the limit of founding out of analytes by atomicabsorption method. It was shown that our results are lower than literature data. This is because of application of standard samples based on acetylacetanates of metals.

Key words: oil products, Zinc, Manganese, atomic-absorption and atomic-emission with inductive connected plasma spectrometry, Bridge-35, ultrasound treatment, acetylacetonates of Zinc and Manganese, analysis, metrological characteristics.

Language: English

Citation: Yurchenko OI, Titova NP, Chernozhuk TV, Kravchenko OA (2018) ATOMIC-ABSORPTION AND ATOMIC-EMISSION WITH INDUCTIVE CONNECTED PLASMA DETERMINATION OF THE ANALYTS IN OIL PRODUCTS WITH USE OF MODERN METHODS OF SAMPLE PREPARATION AND NEW STANDARD COMPOSITION SAMPLES. ISJ Theoretical \& Applied Science, 06 (62): 11-15.

Soi: http://s-o-i.org/1.1/TAS-06-62-2 Doi: crossef https://dx.doi.org/10.15863/TAS.2018.06.62.2

\section{Introduction}

The most important characteristic of oil products is the microelement content that inform us about ways of accumulation and migration, age of oil. The oil microelements, effects negatively on its refining. Use of oil refining products as fuel leads to atmospheric pollution of toxic elements.
This demonstrate us necessity to study microelement composition of oil. In order to do this the methods of the high sensitivity like atomicabsorption and atomic-emission with inductive connected plasma spectrometry are used. The procedure of samples preparation and use of standard composition samples in this method of analysis is discussed by us also. [1,p.93; 2,p.124; 3,p.9; 4,p.615; 


\begin{tabular}{|c|c|c|c|c|c|c|}
\hline Impact Factor: & $\begin{array}{l}\text { ISRA (India) } \\
\text { ISI (Dubai, UAE } \\
\text { GIF (Australia) } \\
\text { JIF }\end{array}$ & $\begin{array}{r}=1.344 \\
=0.829 \\
=0.564 \\
=1.500\end{array}$ & $\begin{array}{l}\text { SIS (USA) } \\
\text { PИНЦ (Russia) } \\
\text { ESJI (KZ) } \\
\text { SJIF (Morocco }\end{array}$ & $\begin{array}{l}=0.912 \\
=0.207 \\
=4.102 \\
=\mathbf{2 . 0 3 1}\end{array}$ & $\begin{array}{l}\text { ICV (Poland) } \\
\text { PIF (India) } \\
\text { IBI (India) }\end{array}$ & $\begin{array}{l}=6.630 \\
=1.940 \\
=4.260\end{array}$ \\
\hline
\end{tabular}

5,p.453; 6,p.173; 7,p.323; 8,p.474; 9,p.1877; 10.p.797; 11,p.17; 12,p.1370; 13,p.270; 14,p.30].

The main purpose of our investigation is the determination of Zinc and Manganese in oil products by methods of atomic-absorption and atomicemission with inductive connected plasma, using of Bridge-35, ultrasound treatment and acetylacetonates analyst as standard composition samples.

\section{Experimental}

For carrying out the experiment we used atomic-absorption spectrometer C-115-MI, atomicemission with inductive connected plasma spectrometer Trace SCAN Thermo Jarrell Ach (USA), ultrasound bath PS-20 and oil products: Okko «Exol 20w-50 economic», Okko «Exol diesel city 1540», TNK «Motor 20w-50», Lukoil «Moto 2T», VAMP «Diesel Turbo», acetylacetone, acetylacetonates of Zinc and Manganese (certified as standard samples by a number of Ukrainian companies), Bridge- 35 .

The analyzed solutions were prepared in such a way: to the sample weight we added $1 \mathrm{ml}$ of saturated $\mathrm{HNO}_{3}, 4 \mathrm{ml}$ of water solution of Bridge-35, $2 \mathrm{ml}$ of acetylacetone and mixed by magnetic mixer within $30 \mathrm{~min}$. The solution was placed into volumetric flack of $10 \mathrm{ml}$ volume and diluted to scale by water SAS solution $(\omega=5 \%$ ) and treated by ultrasound within 10 minutes. In the result we obtained stable and homogenous emulsions which did not exfoliated for 5 days

\section{Results and discussion}

It was established by experiment that Bridge-35 increases an analytic signal at atomic-absorption determination of Zinc and Manganese. By variation of the mass percent of Bridge-35 from 3\% up to $7 \%$ it was found that the analytic signal at determination of Zinc and Manganese increase in 1,5-2 times at Bridge- 35 with $\omega=5 \%$.

To obtain stable emulsions the analyzed and calibrated solutions should be treated by ultrasound. The time of the treatment was varied from 5 up to 25 minutes. It was established that maximal analytic signal is observed at ultrasound treatment of the solutions within 10 minutes. By the variation of weight of the samples from 0,1 up to $0,5 \mathrm{~g}$ it was found that significant systematical error at atomicabsorption determination of Zinc and Manganese is absent.

By the atomic-absorption and atomic-emission with inductive connected plasma method the determination of Zinc and Manganese was carried out in oil products at the set of next parameters: weight of the sample is $0,3 \mathrm{~g}$, Bridge-35 ( $\omega=5 \%$ ), ultrasound treatment during 10 minutes.

It was found out that the use of polyfunctional composition samples is necessary at direct atomicabsorption determination of metals in the samples with organic ligands. An approach of qualitative composition of the calibrated solutions to qualitative composition of the analyzed solutions decreases matrix effects. Using of $\beta$-dicetonates of metals in atomic-absorption spectrometry increases an accuracy of atomic-absorption determination. This results is explained by keeping atoms in flame during longer time. It was shown that application of surfactants decreases viscosity, surface tension, size of drops of the formed sol, increases efficiency of spraying of the solvent, changes redox properties of flame, character of charge distribution in the molecule, efficiency of intra-and intermolecular excitation energy transfer, interphase particles distribution, solubility, rate and equilibrium state of reaction. It was shown also the possibility to carry out analysis in low temperature flame with the increase of selectivity and sensibility in 2-3 times and decrease of limit of determination. Table 1

The results of analytes determination are in

Verification of the validity of the results of atomic-absorption determination of the analyst in samples was done by "injected-found out" method. (Tables 2,3)

In order to find the limit of determination on "pure substances" many times measurement of analytic signal of the "zero solution" (20 values) is done.

The value of the standard deviation is calculated by formula (1)

$$
S_{0}=\sqrt{\frac{\sum_{i=1}^{n}\left(\bar{A}-A_{i}\right)^{2}}{n-1}}
$$

The limit of determination is calculated by formula (2)

$$
C_{\min }=\frac{3 S_{0}}{S}
$$

where $\mathrm{S}$ is the coefficient of sensibility.

The limits of determination of Zinc ( $C_{\text {min }}=0.003$ ) and Manganese $\left(C_{\min }=0.003\right.$ ) were estimated. These limits are less than the corresponding data from literature [15, p.121]. 


\begin{tabular}{|c|c|c|c|c|c|c|}
\hline Impact Factor: & $\begin{array}{l}\text { ISRA (India) } \\
\text { ISI (Dubai, UAE } \\
\text { GIF (Australia) } \\
\text { JIF }\end{array}$ & $\begin{array}{r}=1.344 \\
=0.829 \\
=0.564 \\
=1.500\end{array}$ & $\begin{array}{l}\text { SIS (USA) } \\
\text { PИНЦ (Russia) } \\
\text { ESJI (KZ) } \\
\text { SJIF (Morocco) }\end{array}$ & $\begin{array}{l}=0.912 \\
=0.207 \\
=4.102 \\
=\mathbf{2 . 0 3 1}\end{array}$ & $\begin{array}{l}\text { ICV (Poland) } \\
\text { PIF (India) } \\
\text { IBI (India) }\end{array}$ & $\begin{array}{l}=6.630 \\
=1.940 \\
=4.260\end{array}$ \\
\hline
\end{tabular}

\section{Conclusions}

The application of Bridge-35 $(\omega=5 \%)$ permit us to increase the sensibility in 1,5-2,0 times and ultrasound treatment results the stable homogenous emulsions. Using of acetylacetonates of zinc and manganese as the standard composition samples, we obtain the similar results of study of chemical composition of the analyzed and calibrated solutions. The obtained results permit us to increase an accuracy of determination of Zinc and Manganese in samples.

Table 1

The results of atomic-absorption and atomic-emission with inductive connected plasma determination of Zinc and Manganese in oil products emulsions (with use of Bridge 35 and ultrasound treatment) $(\mathrm{n}=5, \mathrm{P}=\mathbf{0 . 9 5})$

\begin{tabular}{|c|c|c|c|c|c|c|c|c|}
\hline \multirow[b]{3}{*}{ Sample } & \multicolumn{4}{|c|}{ Content of $\mathrm{Zn}, \mathrm{mg} / \mathrm{kg}$} & \multicolumn{4}{|c|}{ Content of $\mathrm{Mn}, \mathrm{mf} / \mathrm{kg}$} \\
\hline & \multicolumn{2}{|c|}{ AAS } & \multicolumn{2}{|c|}{ AES-ICP } & \multicolumn{2}{|c|}{ AAS } & \multicolumn{2}{|c|}{ AES- ICP } \\
\hline & $\overline{\mathrm{C}} \pm \frac{t_{p, f} \cdot S}{\sqrt{n}}$ & $\mathrm{~S}_{\mathrm{r}}$ & $\overline{\mathrm{C}} \pm \frac{t_{p, f} \cdot S}{\sqrt{n}}$ & $\mathrm{~S}_{\mathrm{r}}$ & $\begin{array}{l}\bar{C}_{ \pm} \frac{\mathrm{t}_{\mathrm{p} f} \mathrm{~S}}{\sqrt{\mathrm{n}}} \\
\mathrm{mg} / \mathrm{kg}\end{array}$ & $\mathrm{S}_{\mathrm{r}}$ & $\begin{array}{c}\bar{C}_{ \pm \sqrt{\mathrm{n} f} \mathrm{~s}} \\
\mathrm{mg} / \mathrm{kg}\end{array}$ & $\mathrm{S}_{\mathrm{r}}$ \\
\hline $\begin{array}{c}\text { Okko «Exol } \\
20 \mathrm{w}-50 \\
\text { economic }\end{array}$ & $464 \pm 6$ & 0.01 & $467 \pm 6$ & 0.01 & $1,85 \pm 0,02$ & 0,01 & $1,86 \pm 0,02$ & 0,01 \\
\hline $\begin{array}{c}\text { Okko «Exol } \\
\text { diesel city } \\
1540 »\end{array}$ & $498 \pm 6$ & 0.01 & $500 \pm 6$ & 0.01 & $2,14 \pm 0,02$ & 0,01 & $2,16 \pm 0,02$ & 0,01 \\
\hline $\begin{array}{c}\text { TNK } \\
\text { «Motor } \\
\text { 20w-50» }\end{array}$ & $651 \pm 8$ & 0.01 & $654 \pm 8$ & 0.01 & $2,40 \pm 0,03$ & 0,01 & $2,39 \pm 0,06$ & 0,02 \\
\hline $\begin{array}{c}\text { Lukoil } \\
\text { «Moto 2T» }\end{array}$ & $105 \pm 3$ & 0.02 & $107 \pm 3$ & 0.02 & $2,81 \pm 0,03$ & 0,01 & $2,82 \pm 0,03$ & 0,01 \\
\hline $\begin{array}{l}\text { VAMP } \\
\text { «Diesel } \\
\text { Turbo» }\end{array}$ & $673 \pm 8$ & 0.01 & $677 \pm 8$ & 0.01 & $2,67 \pm 0,03$ & 0,01 & $2,65 \pm 0,03$ & 0,01 \\
\hline
\end{tabular}




\begin{tabular}{l|lr|ll|ll} 
& ISRA (India) & $=\mathbf{1 . 3 4 4}$ & SIS (USA) & $=\mathbf{0 . 9 1 2}$ & ICV (Poland) & $=\mathbf{6 . 6 3 0}$ \\
Impact Factor: & ISI (Dubai, UAE) $=\mathbf{0 . 8 2 9}$ & PUHЦ (Russia) $=\mathbf{0 . 2 0 7}$ & PIF (India) & $=\mathbf{1 . 9 4 0}$ \\
& GIF (Australia) & $\mathbf{0 . 5 6 4}$ & ESJI (KZ) & $=4.102$ & IBI (India) & $=\mathbf{4 . 2 6 0}$ \\
& JIF & $=\mathbf{1 . 5 0 0}$ & SJIF (Morocco) & $=\mathbf{2 . 0 3 1}$ & & \\
\hline
\end{tabular}

Table 2

Verification of the validity of atomic-absorption determination of Zink in the oil products stabilized by ultrasound treatment by "injected-found out" $\operatorname{method}(\mathrm{n}=5, \mathrm{P}=0.95)$

\begin{tabular}{|c|c|c|c|}
\hline Content (Zn), $\mathrm{mg} / \mathrm{Kg}$ & Injected, $\mathrm{Zn} \mathrm{mg/kg}$ & $\begin{array}{l}\text { Found out (Zn) } \\
\overline{\mathrm{C}} \pm \frac{\tau_{p \cdot f^{S}}}{\sqrt{n}}, \mathrm{mg} / \mathrm{kg}\end{array}$ & $\mathrm{S}_{\mathrm{r}}$ \\
\hline \multicolumn{4}{|c|}{ Okko «Exol 20w-50 economic» } \\
\hline 464 & 460 & $920 \pm 11$ & 0.01 \\
\hline \multicolumn{4}{|c|}{ Okko «Exol diesel city $1540 »$} \\
\hline 498 & 500 & $995 \pm 12$ & 0.01 \\
\hline \multicolumn{4}{|c|}{ TNK «Мотор 20w-50» } \\
\hline 651 & 650 & $1300 \pm 16$ & 0.01 \\
\hline \multicolumn{4}{|c|}{ Lukoil «Мото 2Т» } \\
\hline 105 & 100 & $205 \pm 5$ & 0.02 \\
\hline \multicolumn{4}{|c|}{ VAMP «Diesel Turbo» } \\
\hline 673 & 670 & $1340 \pm 17$ & 0.01 \\
\hline
\end{tabular}

Table 3

Verification of validity of Manganese determination in the oil products stabilized by ultrasound treatment by "injected-found out" method $(n=5, P=0.95)$

\begin{tabular}{|c|c|c|c|}
\hline Sample (Mn) & Injected (Mn), mg/kg & Found out $\overline{\mathrm{C}}_{ \pm}^{\frac{\mathrm{t}_{\mathrm{p} f} \mathrm{~S}}{\sqrt{\mathrm{n}}}} \mathrm{mg} / \mathrm{kg}$ & $\mathrm{S}_{\mathrm{r}}$ \\
\hline Lukoil "Mото 2T" & 2,00 & $3,84 \pm 0,10$ & 0,02 \\
\hline TNK "Motor 20w-50" & 2,00 & $4,16 \pm 0,10$ & 0,02 \\
\hline $\begin{array}{c}\text { Okko "Exol 20w-50 } \\
\text { economic" }\end{array}$ & 2,00 & $4,37 \pm 0,11$ & 0,02 \\
\hline $\begin{array}{c}\text { Okko"Exol diesel city } \\
\text { 15w-40" }\end{array}$ & 2,00 & $4,85 \pm 0,12$ & 0,02 \\
\hline VAMP "Diesel Turbo" & 2,00 & $4,70 \pm 0,11$ & 0,02 \\
\hline
\end{tabular}

\section{References:}

1. Kolodyajny A. (2006) Metody i objekty himicheskogo analiza, V.57, pp. 90-104.

2. Khuhawar M.Y. (2010) Crude oil emulsions composition stability and characterization, V.1,pp. $122-144$.

3. AAS, GFAAS, ICP or ICP-MS? Which technique should I use? An elementary overview of elemental analysis. - MA: Thermo Elemental, 2001,11 p.

4. Maristela L.S. (2006) Química Nova, V. 38, pp. 614-621.

5. Stigter J. (2008) Environmental Pollution, V.107, pp. 451-464.
6. Zeiner M. (2005) Microchemical Journal, № 81,pp. 171-176.

7. Gazulla M. (2010) X-Ray Spectrometry, V.39, pp. 321-327.

8. Sample preparation techniques in analytical chemistry / edited by Somenath Mitra. Chemical analysis. New York ,2003, 474 p.

9. Yang L. (2013) J. Chil. Chem. Soc., V. 58, pp.1876-1879.

10. Yáñez J. New approach for understanding the fundamental chemistry of the oxidative sample digestion in spectrochemical analysis / J. Yáñez, C. Sandoval, H.D. Mansilla, D. 
\begin{tabular}{l|lr|ll|ll} 
& ISRA (India) & $=\mathbf{1 . 3 4 4}$ & SIS (USA) & $=\mathbf{0 . 9 1 2}$ & ICV (Poland) & $=\mathbf{6 . 6 3 0}$ \\
Impact Factor: & ISI (Dubai, UAE) $=\mathbf{0 . 8 2 9}$ & PUHЦ (Russia) $=\mathbf{0 . 2 0 7}$ & PIF (India) & $=\mathbf{1 . 9 4 0}$ \\
& GIF (Australia) & $\mathbf{0 . 5 6 4}$ & ESJI (KZ) & $=4.102$ & IBI (India) & $=\mathbf{4 . 2 6 0}$ \\
& JIF & $=\mathbf{1 . 5 0 0}$ & SJIF (Morocco) & $=\mathbf{2 . 0 3 1}$ & & \\
\hline
\end{tabular}

Amarasiriwardena // Applied Spectroscopy Reviews. - 2016. - Vol. 51, N 10. - P. 791-798.

11. Casey J. (2016) Spectroscopy, V. 31, pp. 1122.

12. Yakubenko E. (2015) Inorganic Materials, V. 51, pp. 1368-1372.

13. Yurchenko O.I., Titova N.P. (2008) Jurn. prikl. Spektroskopii, V. 75,pp. 269-273.

14. Yurchenko O.I. Diketonaty metallov kak analiticheskie formy i osnova standartnyh obrazcov sostava dlya spektroskopichsekih metodov analiza: avtoref. dis. na poluchenie nauchnoy stepeni doktora him. nauk: 02.00.02 Hark. nac. un-t im. V.N. Karazina. - Harkiv, 2010. - 31 p.

15. Alemasova A.S., Rokun A.N., Analiticheskaya atomno-absorbcionnaya spektroskopiya. Uchebnoe posobie. Donetsk, 2003, 327 p. 